\title{
Archetypes of Both Sexes and Their Relations as Reflected in To the Lighthouse
}

\author{
LIU Juan, LI Xiang \\ Guangdong Police College, Guangzhou, China
}

\begin{abstract}
Virginia Woolf's To the Lighthouse has gained wide recognition and is regarded by many scholars as her best work. This novel is looked upon as an autobiographical novel of her family, and generally considered to represent Woolf's viewpoint on the relationship between two sexes. In addition to the feminist approach, this paper intends to study complex relations between male and female characters mainly from an archetypal perspective. Based on the study of archetypes in both sexes, we find that the main characters come through various psychological changes, so that their relations can be summed up respectively, as cooperative and finally harmonious.
\end{abstract}

Keywords: archetypes, cooperative, harmonious, relations

\section{Introduction}

Virginia Woolf (1882-1941), an experimental novelist, critic, and essayist of the 20th century, has been regarded as a major modernist writer, whose great achievements in the innovative fictional techniques almost no one can deny. The focus of this paper is on Woolf's To the Lighthouse (1927), which is generally considered to be Woolf's most accomplished work. In this great novel, Woolf explores the complexity of the ongoing relationship between male and female characters.

Many literary critics have contributed a lot to it from a variety of critical approaches, among which the feminist approach is the most popular:

Her feminist ideas are not only expressed in her essays, but also dramatized into the characterization of her novels. She observes the drastic conflict in both sexes, and expresses her ideas of building up the harmonious and stable relation in the midst of antagonism and instability in most of her articles. (Eagleton, 1991, p. 25)

With consideration of the above discussion, this paper intends to study the intricate relation of male and female characters from an archetypal perspective. Emphasis is to be given to the analysis of the major characters-Mrs. Ramsay, Mr. Ramsay, and Lily Briscoe—-to bring out the justification of their significance in relation to the theme. Instead of studying Woolf's theme of depicting an ideal blueprint of harmonious relationship between two sexes from a feminist perspective, this paper tries to study the relationships between two sexes mainly from an archetypal perspective, and sums up two relations between male and female characters, through analyzing their images as archetypes. Thereby, this paper dedicates to elaborating different archetypal

LIU Juan, Lecturer, Department of Public English, Guangdong Police College.

LI Xiang, Associate Professor, Department of Public English, Guangdong Police College. 
images of male and female characters, and to exposing their relations and their psychological changes. In the conclusions section, there is a brief summary of the whole thesis with an emphasis on the aspects of my personal assessment regarding the significance of this study.

\section{The Cooperative Relation Between Two Sexes as Reflected in the Novel}

\section{The Cooperative Relation Represented by Sky Father and Earth Mother}

Neumann proposes "two kinds of features such as positive and negative from archetypal man and woman" (Greenfield, 1983, p. 15). As for this point of view, Greenfield delves back in time and deeper into the psychic roots of the positive image of mother archetype; furthermore, he compares the configuration of mother's stomach as a protective vessel, related to intrauterine containment and shelter (Greenfield, 1983, pp. 15-20). Just like the Great Mother, the archetypal father also has a positive mythical figure, called the Sky Father who "represents himself as a creator and a start-pointing of civilization, and presents himself as the god, Zeus in Greek myth" (Cloman, 1992, pp. 12-25).

\section{Mr. Ramsay as Sky Father}

Mr. Ramsay in To the Lighthouse is both a philosopher with some reputation in his field and a professor in a university. He is logo centric, egocentric, irascible, and unkind, so that everyone around keeps their distance with him. Mr. Ramsay values reason so much as to distain feeling. He hates being indulged in imagination and prefers the pain of accepting objective truth to the happiness of being addicted to deceptive illusions. The above all make him an excessively masculine male. Furthermore, he likes to impose his rigid will upon others. Besides, his sympathy-demanding, vain glory, and sterility in emotion are condemned by his son as "the beak of brass, the arid scimitar of the male” (Woolf, 1994, p. 25). Hence, Mr. Ramsay’s hard-hearted image impels his children and their mother to build up an alliance; it produces an inharmonious atmosphere in the family. From the above, we can clearly observe that Mr. Ramsay embodies some features of the Father Sky: "As a creator and arbiter, the Sky Father is never directly involved in family affair so that he is apart from the chore and children upbringing" (Cloman, 1992, p. 10). What he concerns is "to be assured of his genius, to be taken within the circle of life, to be warmed, soothed, to have his senses restored and to be in the heart of life not only in the family, but all over the world" (Cloman, 1992, pp. 2-3).

Thus, Mr. Ramsay's weakness and limitation lead to his sterility when his relations with others are taken into consideration. His mercilessness upon other people's feeling hinders his communication with them and makes him more disliked than liked. Many people around him have negative views about him rather than positive ones, though they admire his intelligence, courage, and determination. The only one who has a favorable opinion of him is Charles Tansley. Owing to Mr. Ramsay’s weakness in personality, he cannot maintain an intimate relation with anyone around him except his wife. As for most of Romans, "the Sky Father, Zeus usually associates with high office and mighty powers of the bird, he is described as the strict and authoritative god for people” (Head, 1974, p. 16). To sum up, with the image of Sky Father, Mr. Ramsay can never foster up the intimate relation with his family, because Sky Father is often believed to be as lonely as an eagle in sky.

\section{Mrs. Ramsay as Earth Mother}

In contrast with Mr. Ramsay, Virginia Woolf endows Mrs. Ramsay with the image of the Earth Mother. As I have mentioned above, the Earth Mother stands for the unification of universe and signifies the union of life and 
death. She develops her fulfillment in her relationship to those who need help, protection, and development. So she is worshipped as mother and dominator for everything. Mrs. Ramsay is deeply worshipped by Charles Tansley, a young guest, who feels an extraordinary pride when he accompanies her to town and helps her carry her bag. In his mind, Mrs. Ramsay is a beautiful goddess "stepping through fields of flowers and taking to her breast bud that had broken and lambs that had fallen” (Woolf, 1994, p. 25). She is also rich in her inner world. She has some virtues that are intrinsic to her: sympathy, intuition, creativity and self-sacrifice. The portrayal of her is largely based on the revelation of the Earth Mother's image through going into her mind and reporting the impressions and perceptions of other characters.

As the Earth Mother is widely worshiped by fellow men, Mrs. Ramsay brings everlasting influence upon her children in her life. Learning from the history of humankind, we discover that the ancients keep their reliance on a goddess more than on a god (YE, 2001, pp. 27-35). As a symbol of the Earth Mother, Mrs. Ramsay's dominating feature is her sympathy for them when they are in trouble. Sympathy, in this story, carries a series of connotations: love, concern, support, understanding and generosity. Here, sympathy can also be seen as a solution to deal with the inconsistency among family members. In fact, Mrs. Ramsay's sympathy not only goes for her son, she is also deeply concerned for her guests, such as Charles Tansley, Mr. Banks, Mr. Camichael, and Lily Briscoe. As for Charles Tansley, instead of despising his humble family background, improper manners and remarks, Mrs. Ramsay gives him sufficient understanding, encouragement, and respect as equally as to a decent man. With her support, both James and Charles gradually turn to self-assurance. Another example to show Mrs. Ramsay's influential power on others is her concern for Lily.

Lily, in despite of being still critical about Mrs. Ramsay, she acknowledges Mrs. Ramsay's abundance of spirit, a sublime power and heavenly gift. She also has intense gratitude for Mrs. Ramsay's efforts to create harmony among people, which ease the disharmony and perplexity of life. (LI, 2005, p. 34)

Similarly, Mrs. Ramsay’s influential role is also illustrated in her mediation when she is alone. It is at this moment that she lets her mind carried away, looking at the light coming from the lighthouse, and identifies herself with the light. Just like light, Mrs. Ramsay’s spirit enlightens other characters by means of her intuitive understanding of life itself, especially the inadequacy of human relationships (LI, 2005, p. 35). Just as the light, she keeps the balance between light and shade, happiness and sorrow in her family.

From the analysis above, Mrs. Ramsay's position in family seems as the Earth Mother goddess in Greek, is "worshiped not only for her protective, healing, nutritive, loving, and compassionate qualities, but for her strength, initiative, independence, and rational approach to life and its vagaries” (Colman \& Herts, 2000, p. 11). Thus, we can infer that the worship of Earth Mother in ancient people during the course of centuries, and increasing emphasis on spirit while downgrading the flesh may be used as a barometer to measure the greater or lesser role women played in society.

\section{The Harmonious Relation Between Two Sexes as Reflected in the Novel}

\section{Lily as Dyadic Mother}

The most important friend who visits the Ramsay family at their holiday house in the Hebrides is Lily Briscoe, who is an onlooker figure whose function in the novel is to observe life and recreate its reality in her art. She suddenly grasps the meaning of marriage in a moment of awareness, for instance, when she catches a glimpse 
of Mr. and Mrs. Ramsay walking across the lawn. In this moment the couples contribute to her journey in awareness of the relationships between both sexes and to her painting which embodies it, both of which are completed at the end of the novel. Since some scholars believe that Lily is the most typical figure of Virginia Woolf's androgyny theory, Lily likewise becomes a figure of the Dyadic Mother.

The portrayal of Lily is mainly through her perception of herself and of other characters. The maturation in Lily's personality is the process of establishing her own identity and her wholeness. This development illustrates how Lily appears as a rebel and gradually becomes a figure of the Dyadic Mother. The following passage will illustrate that Lily Briscoe is the preferable model of the Dyadic Mother, and it will also show how two characters of both sexes co-exist in her and further, how they finally reach a harmonious ideal state.

In the previous stage described in the novel, Lily has great trouble with her psychological perplexity. As an artist, Lily tries to find truths about human existence, and has her own way to express her impression: "She treats color honestly as Mr. Ramsay does with facts. But as a woman, she is confronted with the subjective and personalized nature of existence, as is Mrs. Ramsay” (LIU, 2002, p. 36). So she is a figure of the Dyadic Mother, and she cannot be entirely man or woman. Although she likes painting, her observation differs from what the famous artists have expressed. In her painting, everything is "pale, elegant and semitransparent” (Woolf, 1994, p. 69). Appropriately, Lily feels that when she stays with the Ramsays she struggles to find harmony between opposite characters inside of her: However, before she finds that, there is a contradiction existing in Lily's mind. What is worst, "she cannot balance these two opposite powers between a man and a woman, so that her painting can’t be successfully finished until Mr. Ramsay’s journey to the lighthouse in last chapter” (LIU, 2002, p. 36). Consequently, we can observe that Lily is struggling with her double identities.

In her relation with Mr. Ramsay, her response is double-sided. She has profound respect for Mr. Ramsay's intelligence, rationality, concentration, and perseverance. On one hand, Lily dislikes him because he is petty, selfish, vain, egotistical, and tyrannical. On the other side, Lily's feelings towards Mrs. Ramsay are ambivalent. She looks upon Mrs. Ramsay as her own mother, who is to be loved and admired. Yet, she still holds an arbitrary view on her. We can interpret this phenomenon by means of the French anthropologist, Rene Girard's standpoints. According to Girard

...the lust of reciprocal imitation is only existed between two opposite powers, and it encourages the imitator to replace his ideal hero's position. Thereupon, such an invisible lust for hero's power will stimulate imitator's hatred and make them becoming the enemy of each other. (2001, p. 108)

Therefore, even if Lily respects Mrs. Ramsay, she is still critical on her on account of her lust of imitation. She blames Mrs. Ramsay for having spoiled Mr. Ramsay with her sympathy. Similarly, Lily regards Mrs. Ramsay's sympathy for other persons as something unnecessary and hypocritical.

Thus, when she stays with the Ramsays, Lily is inclined towards two opposite feelings at the same time. She observes the different traits of the Ramsay couple which illustrate the polarization of men and women. She also has contradictory ideas about each of them. What she feels is one thing; what her other self feels is another; these opposite feelings fight together in her mind. Thereby, Lily's image as a Dyadic Mother at this time brings her much trouble and anguish in her mind. Only ten years later after the death of Mrs. Ramsay does Lily begin to shake off her psychological sufferings. 


\section{The Harmonious Combination Between the Two Sexes in the Novel}

In the novel, Mr. Ramsay's and Lily's changes are initiated from their meeting on the beach. Both of them are drawn together by the mutual admiration for Mr. Ramsay’s boots. Their conversation about the boots prompts their communication for the first time on a face-to-face basis. Later, Mr. Ramsay's offer to teach Lily to tie her shoes moves her very much. She begins to feel differently about Mr. Ramsay. At the same time, the trip to the lighthouse represents the end of two conflicting powers inside both Mr. Ramsay and Lily. Lily's psychological change is also seen to be a result of the trip to the lighthouse. It is in the morning that Lily's mind is full of recollections of Mrs. Ramsay, and Lily has a great longing for her. Furthermore, her memories of Mrs. Ramsay, and her awareness of what she must share with Mrs. Ramsay, are activated. Lily has become someone like Mrs. Ramsay in her appreciation of the value of intuition and sympathy for others:

Her deeper understanding of Mrs. Ramsay and looking into herself makes her transformation from one who wonders rather idly how to appease psychological conflict between two character, to one who values femininity in regulating the opposing forces between men and women as well as that in herself. (LIU, 2002, p. 36)

Finally, through the trip to the lighthouse, both of Mr. Ramsay and Lily reach their psychological peace and unity. Thus, the lighthouse here is not only the wish fulfillment of Mr. Ramsay and Lily, but also the impeller for their androgynous archetypes.

\section{Conclusion}

Regarding the Great Mother and the Father Creator as archetype, this paper exposes various images of male and female archetypes in order to study the relationships between male and female characters in the novel. There are the Sky Father and Earth Mother, and the Dyadic Mother in the Greek myth. Each of them represents a different psychological state of the two sexes. Meanwhile, the relation between the two sexes can also be considered to be a problem of identity for both women and men. Besides, this paper believes in the unity of men and women, as well as the unity of an individual, and tries to lead to an exploration on the seemingly contradictory qualities of men and women in this novel.

Meanwhile, the relations between the two sexes are also represented in the relationships between culture and nature, material and psychological world. Men like Mr. Ramsay are a symbol of civilization and science, while women like Mrs. Ramsay symbolize the power of nature and psyche. Hence, how to deal with two complementary and contrary powers will be a great problem for us.

\section{References}

Colman, W., \& Herts, St. A. (2000). Tyrannical Omnipotence in the archetypal father. Journal of analytical psychology, 45(4), 521-539. Eagleton, M. (1991). Feminist literary criticism. London: Longman.

Greenfield, B. (1983). The archetypal masculine: Its manifestation in myth and its significance for women. Journal of Analytical Psychology, 28 (1), 33-50.

Head, J. (1974). Man myth. Canada: Methuen Publication.

Woolf, V. (1988). A room of one's view in the morden world classicics of Western thoughts. E. E. Knoebel, (Ed.). San Diego: Harcourt.

LIU, N. (2003). Androgynous femal writers in To the Lighthouse. Journal of AnYang Normal College.

LI, S. Y. (2005). Window and lighouse in two sexes. Journal of Zheng Zhou Aircraft Industry College.

YE, S. X. (2001). Goddess of thousands of faces. Shanghai: Shanghai Academy of Social Sciences. 